\title{
Igbo Traditional Morality as a Panacea to Nigerian Security Crises
}

\author{
Anthony Chukwudi Areji, Michael Chugozie Anyaehie \\ Department of Philosophy, University of Nigeria, Nsukka, Nigeria \\ Email: tonyareji@yahoo.com, mikeanyaehie@gmail.com
}

Received 26 February 2015; accepted 16 March 2015; published 18 March 2015

Copyright (C) 2015 by authors and Scientific Research Publishing Inc.

This work is licensed under the Creative Commons Attribution International License (CC BY).

http://creativecommons.org/licenses/by/4.0/

(c) (i) Open Access

\begin{abstract}
There is no doubt that the Nigerian nation is enmeshed in deep and serious crisis now. The most disturbing is the problem of insecurity. Every now and then, many innocent Nigerians are being killed by members of the Boko Haram sect, robbed and kidnapped. Most painful is the way and manner these innocent citizens are being killed in their own country. Regrettably, the security agents are not only loosing out but appear hopeless. Empty promises by the government have not alleviated the situation. The country is fast drifting into anarchy, chaos and doom to the detriment of millions of her citizens. This situation has once again raised the question of national ethics (morality). How were we living together before as one society observing our national norms especially as it concerns respect for human life and how are we going to live together in the future? Reactions trailing the Boko Haram saga have opened up our sordid past with different groups justifying the actions of Boko Haram instead of facing the issue at stake; the sanctity of human life. This calls for a paradigm shift from the use of force to a moral approach. The Igbo communal morality is a humanist morality spelling out personal relationship onye biri ibe ya ebiri (live and let others live). This humanist morality is what we need at this time if we are going to forge ahead as a nation. Everyone should respect his/her neighbour's right to feely and lawfully live his/her life in accordance with existing norms irrespective of any differences. This universal (Igbo) morality will not only curb the security crises in Nigeria but also ensure a harmonious co-existence among the various tribes and the entire humanity at large.
\end{abstract}

\section{Keywords}

Boko Haram, Security, Igbo, Morality, Nigeria, Nigerian

\section{Introduction}

There is no gain saying that this is not the best of time for Nigerians security wise. The nation is engulfed in se-

How to cite this paper: Areji, A. C., \& Anyaehie, M. C. (2015). Igbo Traditional Morality as a Panacea to Nigerian Security Crises. Open Journal of Political Science, 5, 102-108. http://dx.doi.org/10.4236/ojps.2015.52012 
rious security crisis that seems almost intractable. These crises have assumed such dimension that not only Nigerians are worried but the entire world. Ranging from the Niger-Delta crisis to issues like armed robbery, kidnapping and the latest onslaught of Boko Haram, the story is the same and the consequences bizarre. How a fanatical militant group grew to terrorize Africa's most-populated country. A brief review how this militant group came up might be apposite here. Ford (2014: p. 23), gave a short review on how the sect came to be a security threat to Africa's most populated country.

Boko Haram appeared in the consciousness of most Westerners for the first time in April of this year. But the group is not a new arrival on the scene. It has been a growing force in Nigeria for over a decade and has deep roots in the country's social development going back even further. Its rise is not an accident and signals the emergence of a dangerous, militant religious movement that threatens Nigeria's survival as a nation-state. Boko Haram's story begins with a preacher named Mohammed Marwa, born in 1927. At about age eighteen, he moved to Kano, in what is today northern Nigeria, and began a career as a preacher. His sermons were extreme and often bizarre. He raged against Western culture and its popularity in Nigeria so virulently that he became known as Maitatsine, meaning "The one who damns". He declared that reading any book other than the Koran was sinful and a sign of paganism. This included a prohibition on reading the Hadiths or Sunnah, the doctrinal equivalent of a Catholic Priest telling parishioners not to read the works of St. Augustine because they do not appear in the Bible. Near the end of his life, he came dangerously close to declaring that he, not Muhammad, was Allah's true prophet.

After this brief overview of the sect's origin as a security threat to Nigeria, it significant to observe that as a result of their activities, many lives and property are lost on daily basis as a result of these security crises. Most worrisome is the hopelessness of the present government in handling these security crises. Nigerians are losing hope in the various promises of government to bring the "perpetrators of these heinous crimes to book". Nigerians are now living on a precarious hope of not knowing who would be the next victim.

The question on the lips of everybody is what is the solution to these security crises which have ravaged the country like a harmattan fire and which is threatening not only the corporate existence of the nation but also challenging her foundation as an entity. Many solutions have been suggested and even some of them implemented without success. It seems that both legality (constitution) and force (security agents) have failed. Dialogue is almost impossible especially with the Boko haram group because of the complex nature of its demands. The question now is what next. This is the crux of the matter which this paper wants to address. Before doing this, let me clarify and expose the knitty-gritty of the concepts and issues involved.

\section{Igbo Traditional Morality}

Because of the nature of this paper, it is needless going into the various historical theories of the Igbo people especially the theories of origin and migration. Nevertheless, it is pertinent to note that the Igbos are the people occupying the South-East geographical zone of Nigeria. The Igbos are also found in some parts of the South-South geo-political zone of the country. The Igbos are the third largest tribe in Nigeria and are found in every nook and cranny of the country struggling to eke out a living. In short they are the most mobile people in Nigeria.

Igbo traditional morality is enshrined in what is referred to as OMENANI or OMENALA. According to Nwala, among the Igbos, "their philosophy of nature and life, its general principles and social practices are embodied in the concept of Omenala. What is Omenala"? In the words of Nwala (2010: p. 76).

This is the totality of the lore of the land, customs and tradition, a complex of beliefs and practices which every Igbo person inculcates as a guiding philosophy and code of behaviour.

All the taboos, totems and prohibitions hedged around Omenala are designed to ensure that the natural order is not violated and that proper relationship among spirits, between spirits and men, among men, between men and the lower beings, between husband and wife, child and parent, among kinsmen etc; are maintained. The gamut of natural order stretches from the lightest principles and basic beliefs about life and the universe to the principles that guide economic pursuits and the lowest items of etiquette. In all, there is unity of all things. The highest principle within Omenala, which underscores the behaviour and actions of all beings, is ofo (justice), symbolized in "ofo stick" held by elders, priests and the initiated. The holders of ofo are the guardians of Omenala and the its codes, which protect the cosmic, natural and social balance. 
Generally among the Igbos, the norm of right or wrong is said to be social custom. As with most societies in the world, among the Igbos, the good is usually that which receives the community's approval while the bad is that which the community prohibits or frowns at. While the good actions build up society, the bad ones tear it down. One is social, the other anti-social. With the Igbos, omenala or social custom is the means by which society enforces conformity to its rules.

“Omenala” derives from three Igbo words, “Ome” (that which obtains); “na” (in); “ala” (land or society). According to Okorocha (1987: p. 101), “the moral code of Iboland commonly spoken as 'Omenala' defines the various aspects of behaviour and social activities that are approved while at the same time indicating those aspects that are prohibited" "Omenala" then is the means by which "the social ethos is measured, and the values of the society... controlled from one generation to another and the processes of socialization through which the education of the young ones are facilitated".

\section{Aspects of Igbo Traditional Morality (Omenala)}

Morality is aspects of values; and according to Nwabuisi (2001: p. 1), values are fundamental to all human activities and actions all over the world. Values are therefore universal phenomena. When moral values is in focus, it becomes distinctive to a large extent as what constitutes moral value in one ecological habitat may not retain the same position in a different ecosystem. There are traditional moral values that are well known among the Igbos of the south-Eastern Nigeria. These moral values may not be peculiar to them alone but for purpose of familiarity with the language and life pattern, I have decided to choose the Igbo race. Similarly, if these moral values are shared among other ethnic groups, efforts at broadening and universalizing them become a higher task.

According to Ugwu (2004: pp. 289-290), these traditional moral values among the Igbos include Truth, and a life of rectitude humility, loyalty or obedience, honesty, sincerity/justice, goodness, hospitality, chastity before and in marriage among the women, respect for sanctity of human life, and the recognition and belief in the existence of God. He further states that moral values have the potent powers of facilitating and creating the enabling environment for societal development in Nigeria because at any level of disobedience or infringement of these highly valued moral elements, the culprit is always punished either by the living or highly revered ancestors. Punishment therefore, deter people from being immoral. For Mbiti (1969: p. 173).

It is believed in many African societies (Igbo inclusive) that these morals are given to them by God from the beginning. This provides an unchallenged authority for the morals. It is also believed or thought that some of the departed and the spirits help watch over people to make sure that they observe the moral laws and are punished when they break them deliberately or knowingly. This additional belief strengthens the authority of the morals.

Ugwu (2004: p. 290) notes that it is the above that underscores the relevance of moral values in the development of a society. If there are no sanctions attached to moral laws, its violation will be done with impunity especially in our society where the might is always right.

For Okafor (1992: p. 32), Igbo religion and morality are closely interwoven. In fact, they are not only complementary but also inseparable. In spite of this marriage of morality and religion, there is nevertheless a well defined code of morality in Igbo society. Basden as quoted in Okafor supports this claim that in the majority of Ibo towns a very clearly defined codes of moral exist theoretically. Infringements on these laws may lead to severe penalties being inflicted. Many have criticized Basden for asserting the theoretical existence of codes of moral which has the enforcement of severe penalties. If it has the enforcement, its existence cannot be at the theoretical level.

Okafor (2004: p. 32) maintains that Igbo moral ethics revolves around justice. According to him, the just man in the Igbo moral estimation is one who gives to everyone what is his due; one who tells the truth regardless of who or what is at stake; one who is objective in his judgment. He goes further to state that for the Igbo the classical sinner is the thief. This is because theft is seen as an aggression and infringement on other people's rights which is a violation of social justice. This very statement raises the question of governance and accountability on the part of our leaders. What is happening to our vast natural resources and the revenue accruing from them? Why are the masses becoming more impoverished and unemployment every where? Can't we link the security crises in the nation to this stealing called governance? I will revisit these later. He sums up with the Igbo adage concerning justice "Egbe belu, ugo belu, nke si ibe ya ebena nku kapu ya” (let the kite perch and let the eagle 
perch, whichever says that the other will not perch, let its wing break off). This is summed up as "live and let others live".

Nwala (2010: p. 205) identifies the character of Igbo traditional morality to be not only traditionally enjoined system of individual responsibilities, but the community as a whole is held responsible for the conduct of each individual member. A community is made to suffer because of the bad conduct of any one of its members; therefore, it is the responsibility of the whole community to control the conduct of its members. The dos are actions enjoined and they don't prohibit. He went further to identify the negative and the positive moral values. Negative moral values are mostly definitive prohibitions of improper behaviours including the more serious ones in the nature of taboos, e.g. patricide, incest, killing of sacred animals, murder, women climbing palm trees abuse of elders, rules against improper sexual relations, stealing, lying, secretive life, poisoning, witchcraft etc. There are also prohibitive rules which pertain to people's roles or stations in life. Violations of most of these are "aru" (abomination) which call for serious rituals and sanctions.

The positive moral values according to Nwala (2010: p. 207) are of two categories. These are traditional moral values and individual virtues. Traditional moral values stress the authority and pre-eminence of the community while personal virtues are moral values and principles necessary for the individual to reach the ideal state of life but presuppose the traditional values. These positive traditional values are;

1) Pre-eminence of the community - There is a popular adage, which underpins the principle, which holds the being of the community as prior to and supreme over that of its individual members. It is said that no man however great, can win judgement against his clan. An individual or any section or part of the community is bound to respect and obey the judgement of the entire community, no matter harsh. In principle, the supremacy of the community is unquestionable, and in fact, the community as it were does no wrong, because it is also a democratic order, the embodiment of the collective aspirations and destiny of all its individual members. In short, to live is to live in a community:

2) Justice- Justice is defined in such proverbial rules as

a) Onye emegbula ibe ya — do not sin, cheat, harm or offend your neighbour.

b) Onye emegbula chi ya—do not offend your god or your chi. This principle implies respect for the lore of the land.

c) Nwa mmuo emegbula nwa mmadu, ma nwa madu emegbula nwa mmuo. The spirit should not offend man, and vice versa.

d) Egbe bere Ugo bere; nke si ibe ya ebela, nku kwapu ya nike. Let the kite perch, and let the eagle perch, which ever tries to prevent the other from perching, let his wings fall off.

e) Ihe madu si ibe ya emela ya, ya emela ndi ozo. Do not unto others that which you would that others do not do to you.

These are principles of justice that regulate both inter personal relations and the relations between man and other supra-sensible entities.

Other positive traditional values include peace, order and harmony, traditional co-operation honesty, hospitality, respect for seniority and constituted authority, generosity/altruism and respect for the dignity and sanctity of human life. In deed for the traditional Igbo, human life is so sacred that whoever violates this moral principle is seriously sanctioned. Personal virtues include ability, strength, intelligence, wisdom, courage, bravery industry and patience etc.

One of the most significant features of Igbo tradition morality, like most other traditional or customary systems, is the indispensable role of sanctions; ranging from ostracism, propitiatory sacrifices, to simple apology or doing some work to appease the anger and assuage the feeling of the man wronged as well as the anger of the deities and gods who are the guardians of the system. There are various institutional devices which help to sustain the moral order in the traditional society. These include priestly cults, secret societies, titled associations and association of age grades and even women and youth associations.

I have done an expose of the Igbo traditional morality as expounded by various authors. My attention will now turn to Nigerian security crises.

\section{Nigerian Security Crises}

There is hardly any society without security problems. However, it assumes a crisis point when the problem is not yielding to any solution. Today, Nigerian security problems have defied all solutions thus resulting in the 
security crises we are in this present moment. These security crises are too numerous to mention. Before now, the problems were mainly armed robberies, sponsored killings like the one involving a serving minister of justice and Attorney General of the federation Chief Bola Ige, sudden disappearances of human beings, ritual killings and most importantly the Niger-Delta crisis. In the above mentioned problems, lives were always lost with the security agents promising to fish out the culprit with little or no success. However, it should be observed that the number of lives lost in the above situations are child play compare to the present security crises especially with Boko Haram and other sectarian and ethnic violences ravaging the country. This situation is such that nobody is safe. It is on record that Boko Haram attacks have claimed thousands of life. The January 20, 2012 attack on Kano claimed more than 250 lives. These lists are endless and more precarious is the fact that there is no end in sight.

The Arabian Journal of Business and management Review (OMAN chapter) Vol. 1. No. 9 April 2012 captures the situation thus; the atmosphere of insecurity currently pervading the nation is now worsened by the allegation of complicity among high-ranking security personnel. The jury is still out as to whether terror suspect, Kabiru Sokoto, actually escaped but the manner in which the drama unfolded has given Nigerians cause to fear about the competence of those charged with the nation's security. The journal insist that it is axiomatic to posit that there is a large consensus of opinion that government must find a quick-fix solution to the problem, and then a lasting solution. This is because there is no way government will continue to spend the huge chunk of money it has been spending on security without providing security to Nigerians. Some Nigerians and groups are so incensed with the rising insecurity in the polity that they are calling for Jonathan's resignation. There is also the belief that such calls will continue to rise until there is a remarkable improvement in the maintenance of security in the land, as there is a rising impatience among the populace (Okpaga et al., 2012: p. 2).

Armed robbery operations are also on the increase. There were periods when some cities in Nigeria were no go areas because of incessant bank robberies with the attendant casualties. In many parts of Nigeria, kidnapping is no longer news but a daily reality the citizens have to live with. Sponsored and ritual killings are on the rise. Apart from few successes in arresting and foiling attempts at bank robberies, there is no significant success in arresting culprits of other crimes. The question on every lip is what is responsible for these security crises. Many answers and theories have been propounded. Let us examine these answers and theories.

\subsection{Ethno-Religious Conflict}

Traditional and societal conflicts according to Ibrahim and Igbuzor have emerged as a result of new and particularistic forms of political consciousness and identity often structured around ethno-religious identities. In all parts of Nigeria, ethno-religious conflicts have assumed alarming rates. It has occurred in places like shagamu (Ogun state), Lagos, Abia, Kano, Bauchi, Nasarawa, Jos, Taraba, Ebonyi, Enugu and virtually all other parts of Nigeria. Groups and communities who had over the years lived together in peace and harmony now take up arms against each other in gruesome wars. The claim over scarce resources power, land, chieftaincy, local government, councils, control of markets, "Osu caste system" and sharia among other trivial issues have resulted in large scale killings and violence amongst groups in Nigeria. In these conflicts, new logics of social separation and dichotomy have evolved in many communities in Nigeria. There is the classification of the "settler" and "indigene, "Christian" and "Moslem" and "Osu” (slave) and "Nwadiala” (free born). These ethno-religious identities have become disintegrative and destructive social elements threatening the peace, stability and security in Nigeria (Okpaga et al., 2012: p. 1).

\subsection{Political Based Violence}

Politics in Nigeria has always been characterized by anxiety and violence. In this case, dialogue, negotiation and consensus are played down. Some politicians who have lost power want to regain it and those who are in power want to keep it at all cost. Put differently, the quest for political power among those elites that won it before, those that lost it and those who want it back. Many people are of the opinion that the current security crises in the nation especially the emergence and brutal onslaught of Boko Haram are tied to the shift of power from the North to the South. To this end, inter and intra-political party conflicts have become rife in which politicians are deploying large resources to out-do each other, changing rules and legislations of the political game, distorting laws and employing violence and political assassination to settle political scores.

Another dimension of politically motivated violence is the attitude of the leaders toward the citizens of the 
country. The few leaders and their cronies are living in stupendous wealth while the vast majority of the citizens are living below poverty level. Unemployment, hunger and starvation, homelessness, destitution, sicknesses and diseases abound in country of great wealth. The deprived masses especially the youths have no option than to indulge in crime to make a living.

\subsection{Economic-Based Violence}

This thesis is known as "political economy violence". Recent researches and writings across the globe and across political divide have laid much emphasis on the role of resources in generating conflict which is a major cornerstone of economic - based violence. Cries of resource control and revenue sharing regularly rent the air between proponents and opponents. The Niger-Delta crisis is a good example of this type of violence. In deed the emergence of kidnapping in Nigeria is directly linked to the Niger-Delta crisis where militants were in the habit of kidnapping expatriates and oil workers for a huge ransom to be paid in exchange for their release. Unfortunately, some of their victims were either killed or died in the process.

Similarly, because oil wealth flows to the powerful and elite, social services, public safety programmes and education are of very low quality or nonexistent and Nigeria ranks among the world's poorest populations, with $75 \%$ of the population living on $\$ 1.23$ per day. This situation will naturally generate unrest and insecurity (Thomson, 2012: p. 3).

\subsection{Organised Violent Groups}

Organized violent groups take varying dimension and forms. These include: ethnic militia, vigilantes, secret cults in tertiary institutions and political thugs. Various reasons and circumstances account for their emergence. The causes of the manifestations include the culture of militarism that has its antecedents in military rule, the failure of the state and institutions, economic disempowerment, the structure of the state and Nigeria's federalism, non-separation of state and religion, politics of exclusion, culture of patriarchy and gerontocracy; and ignorance and poor political consciousness (Okpaga, 2012: p. 6).

I have dealt exhaustively with the theories and causes of security crises in Nigeria. Some of these problems have been partially addressed especially the Niger-Delta crises by the granting of Amnesty to the militants when it was obvious to the government that it cannot settle the crisis through arms struggle with the militants. The other problems remain largely unsolved. The obvious fact is that legality and force have failed. The coercive instrument of the state has also failed. The question now is, when all these have failed what else remains the alternative? This is the crux of this paper.

\section{Towards Solving the Problem of Security Crises in Nigeria; Igbo Traditional Morality Option}

The dynamism in the human person lies in his/her ability to try many options; not relying on conventional or constitutional approaches only. In so many societies what they cannot achieve with science and technology were achieved through humanism and religion. Nigeria security crises have defied both the conventional and constitutional approaches as well as the use of science and technology (force). The need for an alternative is not only imperative but urgent if our corporate existence is to be sustained and the security of the citizens guaranteed.

Igbo traditional morality, like those of other African societies was traditionalistic and humanistic in nature. In traditionalistic societies, virtue and goodness are often seen as a means of realizing the social harmony of the group. They function to promote order, peace and a camaraderie feelings among the individuals who make up the society (Agulanna, 2007: p. 11). Many scholars like Roubiczek as cited in Agulanna argues that "to subordinate the good to another purpose, such as usefulness for society, falsifies its nature and thus falsifies morality". However, scholars who hold similar opinions with Roubiczek are wrong because traditional morality is backed with sanction and any member of the group is punished for his wrong doing which upset the well-being of the society.

\section{How Can Igbo Traditional Morality Solve the Problem of Nigeria Security Crises?}

We have itemised the salient areas in Igbo traditional morality which can serve as a fulcrum for promoting national security. I have also identified the various causes of national security crises in which both the government 
and the citizens are contributory agents. Among these salient points in Igbo traditional morality are justice, pre-eminence of the community, respect for the sanctity and dignity of human life, love for oneself and his/her neighbour, belief in goodlife and the reward for after life among other ones.

Many have identified injustice as the cause of the present security crises in Nigeria. This injustice stems on the part of government for failing to cater for the citizens by providing them what rightly belongs to them. The glaring disparity in the country is against Igbo traditional morality which emphasized Onye rie ya nye nwa nna ya (if you eat you give to your brother). The emphasis on one brotherhood is a manifestation of the Igbo (African) extended family relation. The government instituted injustice through unfair sharing and the masses are angry. Similarly, government has failed to institute a good machinery for the dispensation of justice and people are resorting to jungle justice. The moral code of "live and let others live" is often violated by the government who wants to live and let others die. The promises of democracy dividend have disappeared to the wind. The 2012 flood disaster in the country has equally exposed the insensitivity of government to the right and plight of the masses. There are demonstrations in most of the refugee camps because of total neglect, yet our leaders are enjoying unimaginable comfort. The feeling of neighbourliness and concern has completely disappeared and the result is deep rooted sentiment on the part of the citizens which is finding outlet in crime and other vices.

On the part of the citizens, their action is a follow up to that of the government. Government has not done anything substantial to convince the citizens that this is one country, one people and one destiny. Some national policies like "character commission", Educationally less Disadvantage states and others that favour a particular area of the country is a manifestation that we are not one family. Igbo traditional morality emphasizes meritocracy and consensus. These are lacking in our national life. The bottom line is that Nigeria as a nation does not have a national morality which should be a foundation for our constitution. This lacuna should be filled. The question is how.

Morality is imbibed through education and generational transfer. This is the time to begin because our past is empty morally as a nation. Regional and ethnic alliance have always taken the place of national affiliation. That is why one tribe will not have any qualm of conscience slaughtering the other; and sometimes with support from their leaders. This is a clear indication of lack of respect for the dignity and sanctity of human life. Man should be an end in itself not a means to any other end. Government should include in our curriculum these salient points of Igbo traditional morality which emphasize the universality of all human person. Our leaders should live and act in accordance with these tenets because when our leaders live morally, the citizens are bound to follow.

\section{Conclusion}

As a nation, we need security of lives and property anywhere in this country. This cannot come in a vacuum. Our constitution and other coercive instruments of the state have also failed. The option is the search for a moral principle where we will be judged by our conscience and not by any other means that can be adulterated. This moral principles is found in Igbo traditional morality because of its humanistic and universal qualities.

\section{References}

Agulanna, C. (2007). Journal of Philosophy and Religion, 8, Thailand: Assumption University.

Ford, J. (2014). How Boko Haram Was Born. Washington DC: National Interest Centre.

Mbiti, J. (1969). African Religion and Philosophy. London: Heinemann.

Nwabuisi, M. E. (2001). Vlaues and Education. Onitsha: Spiritan Publication.

Nwala, T. U. (2010). Egbo Philosophy (2nd ed.). Abuja: Niger Books.

Okafor, F. U. (1992). Igbo Philosophy of Law. Enugu: Fourth Dimension Publishing Co. Ltd.

Okorocha, C. C. (1987). The Meaning of Religious Conversion in Africa. Brookfield: Brookfield Publishers.

Okpaga, A. (2012). Arabian Journal of Business and Management Review, 1.

Roubiczek, P. Ethical Values in the Age of Science. Agulanna, 11.

Thomson, V. (2012). Boko Haram and Islamic Fundamentalism in Nigeria. Global Security Studies, 3.

Ugwu, C. O. T. (2004). Religion and Societal Development. Lagos: Merit International Publications. 